\title{
Instability of the expression of morphological and phenological descriptors to environmental variation in white oat
}

\section{Instabilidade da expressão de descritores morfológicos e fenológicos à variação ambiental em aveia-branca}

\author{
Jossana Santos ${ }^{1 *}$; Simone Meredith Scheffer-Basso ${ }^{2}$; \\ Nadia Canali Lângaro²; Sandra Patussi Brammer ${ }^{3}$
}

\begin{abstract}
Morphological and phenological characters are used in the selection, breeding, and description of plant varieties with varying genotypes. The stability of these descriptors in the face of environmental changes can determine their usefulness in situations where plant varieties must be reliably identified. The objective of this study was to verify the expression of morphological and phenological descriptors and use them to distinguish between white oat cultivars (Avena sativa L.) in two growing periods. For this, five cultivars, protected and belonging to four breeders, referred to as G1, G2, G3, G4, and G5, were sown in the typical growing season in southern Brazil (autumn-winter) and outside that period (winter-spring), and grown for forty days. The experiment was established in the field, in a randomized block design replicated three times. The cultivars were evaluated for 42 descriptors ( 15 quantitative and 27 qualitative). Quantitative data were analyzed by analysis of variance, the comparison of averages, and multivariate analysis by generating average euclidean distances. Qualitative data were analyzed by mode determination, followed by obtaining the similarity index. The relationship between cultivars was illustrated by dendrograms. The stability index for each descriptor was calculated. A genotype $\mathrm{x}$ environment interaction was observed for 28 descriptors. The stability of descriptor appearance and persistence over the growing season was higher in qualitative (44\%) than in quantitative (7\%) descriptors. The most stable qualitative descriptors were lemma color, hairiness of the upper node, flag leaf position, hairiness of the base of the grain, basal grain length, and rachilla length. The most stable quantitative descriptor was flag leaf length. Shifting the white oat growing season from autumn-winter to winter-spring reduced the cycle and modified the expression of most descriptors by changing the phenotypic distinctness between cultivars.
\end{abstract}

Key words: Avena sativa L. Genotype x environment interaction. Morphology. Phenology.

\section{Resumo}

Caracteres morfológicos e fenológicos são utilizados na seleção, cruzamentos e descrição de genótipos, sua instabilidade frente a alterações ambientais pode determinar o seu valor na etapa de proteção de cultivares. Este trabalho foi desenvolvido com o objetivo de verificar a expressão de descritores morfológicos e fenológicos e, consequentemente, a dissimilaridade entre cultivares de aveia-branca (Avena sativa L.) em dois períodos de cultivo. Para isso, cinco cultivares, protegidas e oriundas de quatro

\footnotetext{
${ }^{1}$ Discente, Programa de Pós-Graduação em Agronomia, Universidade de Passo Fundo, UPF, Passo Fundo, RS, Brasil. E-mail: jojossana@hotmail.com

2 Prof $^{\text {as }}$, Faculdade de Agronomia e Medicina Veterinária, UPF, Passo Fundo, RS, Brasil. E-mail: sbasso@upf.br; nclangaro@upf. br

${ }_{3}^{3}$ Pesquisadora, Empresa Brasileira de Pesquisa Agropecuária, Embrapa, Passo Fundo, RS, Brasil. E-mail: sandra.brammer@ embrapa.br

* Author for correspondence
} 
obtentores e, aqui, codificadas (G1, G2, G3, G4 e G5), foram semeadas dentro do período recomendado para a cultura no sul do do Brasil (outono-hibernal) e fora desse período (hiberno-primaveril), com intervalo de quarenta dias. O experimento foi estabelecido em campo, em blocos casualizados, com três repetições. As cultivares foram avaliadas quanto a 42 descritores (15 quantitativos e 27 qualitativos). Os dados quantitativos foram submetidos à análise de variância, seguida da comparação de médias, e à análise multivariada, por meio da geração da distância euclidiana média. Os dados qualitativos foram submetidos à determinação da moda, seguida da obtenção do índice de similaridade. A relação entre as cultivares foi ilustrada por meio de dendrogramas. Foi calculado o índice de estabilidade dos descritores. A interação genótipo $\mathrm{x}$ ambiente foi observada em 28 descritores. A estabilidade de expressão, à alteração no período de cultivo, foi maior nos descritores qualitativos (44\%), quando comparada aos quantitativos (7\%). Os descritores qualitativos mais estáveis foram: cor do lema, pilosidade do nó superior, posição da folha-bandeira, pilosidade da base do grão, comprimento dos pelos basais do grão e comprimento da ráquila. $\mathrm{O}$ descritor quantitativo mais estável foi o comprimento da folha-bandeira. $\mathrm{O}$ atraso no período de cultivo da aveia-branca, de outono-hibernal para hiberno-primaveril, reduz o ciclo da cultura e modifica a expressão da maioria dos descritores, alterando a dissimilaridade fenotípica entre cultivares.

Palavras-chave: Avena sativa L. Morfologia. Fenologia. Interação genótipo x ambiente.

\section{Introduction}

Oat (Avena sativa L.) is among the most important cereals for human consumption and animal feed. The economic importance of this cereal creates challenges for research on cultivar improvement and protection because oat is a multipurpose crop with high nutritional value. Oat germplasm variability is analyzed using descriptors in crop breeding programs, similar to that in other species.

These descriptors are qualitative or quantitative morphological and phenological traits. Quantitative descriptors are traits based on data generated by measurements or counts using numerical values and scales, whereas qualitative descriptors are traits based on established patterns that are visually assessed (BIOVERSITY INTERNATIONAL, 2007). Descriptor choice for a given plant species is governed by the most striking morphological, physiological and molecular characteristics that may be transmitted to each generation as that cultivar is propagated (BRASIL, 2011).

In Brazil, descriptor choice is the responsibility of the National Plant Variety Protection Service (Serviço Nacional de Proteção de Cultivares SNPC), whose legislation follows principles set by the International Union for the Protection of New Varieties of Plants (Union pour la protection des obtentions végétales - UPOV) convention. For provision of this service, descriptor profiles are given which include: a) name, b) expression status, which documents variation in measurements or observations, and c) method with which they should be evaluated (BIOVERSITY INTERNATIONAL, 2007). Lists of descriptors are used, especially in genetic breeding programs, from the germplasm characterization and evaluation phase to the cultivar protection stage. Germplasm characterization and evaluation describes the qualitative and quantitative traits of accessions of a given species that can be used to differentiate them. This process assesses the usefulness, structure, genetic variability and the relationship between these traits. Their characterization determines highly heritable traits that are easily identified and expressed in all environments, whereas the preliminary evaluation is based on key agronomic traits of the crop (IBPGR, 1985). Thus, morphological characterization provides a set of data on the genetic variability of materials (GUIMARÃES et al., 2007). This is essential for genetic breeding programs because it identifies combinations that may result in high heterosis, and enhances variability when crossing different genotypes, which raises the prospect of selecting superior segregants (BEZERRA NETO et al., 2010). In the cultivar protection stage, wherein the breeder submits the new plant variety 
for protection by government agencies, the list of descriptors should be submitted along with the material in question to prove its distinctness.

Ideally, descriptors should remain stable under environmental changes to ensure their reliable use for phenotypic profiling of genotypes. Preferably, traits affected by environmental changes to some extent should be avoided (DIEDERICHSEN, 2008). Timing of the growing season is one factor that increases environmental variation because the crop is subject to varying meteorological conditions. The growing season indicated for a crop ensures compliance with the rules of distinctness, uniformity and stability (DUS) tests (CBPA, 2014), because genotype protection is subject to morphological description. Sowing outside of the recommended season may result in different phenotypes displayed for a particular genotype, which would change how comparisons are made with other genotypes. This creates challenges for breeders, farmers, and supervisory bodies in particular.

Timing of the oat growing season affects yield and phenology (FLARESSO et al., 2001; VALÉRIO et al., 2009; JEHANGIR et al., 2013), and changes the expression of traits, particularly the vegetative cycle and plant height (VALLE, 2009). However, little is currently known about the stability of most Avena L. descriptors when timing of the growing season is changed. The objective of this study was to assess whether variation in timing of the growing season affects expression of morphological and phenological descriptors and thus distinction between oat cultivars.

\section{Material and Methods}

Five registered and protected oat cultivars, derived from four breeders and referred to as G1, G2, G3, G4 and G5, were evaluated for expression of 42 descriptors. The study was conducted in 2014 , in Rio Grande do Sul, at $28^{\circ} 15^{\prime} \mathrm{S}$ and $52^{\circ} 24^{\prime} \mathrm{W}$. The study site was at $687 \mathrm{~m}$ average altitude, with a humid subtropical climate (MALUF, 2000), and in a typical dystrophic Red Latosol. The bifactorial experiment consisted of 5 cultivars $\times 2$ growing seasons, established in a randomized block design, with three replicates. The experimental units were $1 \mathrm{~m} \times 5 \mathrm{~m}$ plots, consisting of five rows $0.20 \mathrm{~m}$ equidistant from each other. The growing seasons, meaning the period between sowing and ripening, were established and referred to as follows: (1) Autumn-Winter (A-W): from 06/12 to 09/19/2014 and (2) Winter-Spring (W-S): from 07/22 to 10/29/2014. The A-W season corresponded to the recommended growth season for oat in the southern region of Brazil, which, according to criteria of the Brazilian Oat Research Commission (CBPA, 2014), should commence with sowing from May to June. During the course of the experiment, the growing seasons were monitored regarding average monthly temperature, minimum and maximum daily temperatures, soil temperature and rainfall (Table 1).

Mechanical sowing was carried out at a density of 300 viable seeds $/ \mathrm{m}^{2}$, and fertilization was performed as recommended (CBPA, 2014) based on soil analysis results. Weeding and disease control was administered by two applications of tebuconazole. The experiment included 42 descriptors, of which 28 are included in the list required by the Ministry of Agriculture, Livestock and Food Supply (Ministério da Agricultura Pecuária e Abastecimento - MAPA; BRASIL, 2002) for oat cultivar protection purposes and meet the minimum criteria of the UPOV. Descriptor expression evaluation in cultivars was performed according to instructions for conducting the Avena L. DUS tests. Fourteen traits were evaluated including flag leaf length and width, caryopsis length, flag leaf, glume and lemma waxiness, caryopsis hairiness, and number of days following seedling emergence until tillering, booting, complete booting, anthesis, watery ripe grain, soft dough grain and ripening phases in the crop cycle. Of all oat descriptors, 
15 are quantitative traits, which were assessed by length, width, number or density measurements, and 27 are qualitative, multicategoric and binary traits, subjectively evaluated in compliance with regulations. The evaluations occurred at specific phenological stages, according to recommendations of the MAPA (BRASIL, 2002), following the scale by Zadoks et al. (1974).

Table 1. Mean minimum (mAT), mean maximum (MAT), average air (AAT) and soil (ST) temperatures, and rainfall recorded during each phenological phase of oat cultivars grown in the A-W and W-S growing seasons in southern Brazil.

\begin{tabular}{|c|c|c|c|c|c|c|c|c|c|c|}
\hline \multirow{2}{*}{ Phenological phase } & \multicolumn{2}{|c|}{$\mathrm{mAT}\left({ }^{\circ} \mathrm{C}\right)$} & \multicolumn{2}{|c|}{ MAT $\left({ }^{\circ} \mathrm{C}\right)$} & \multicolumn{2}{|c|}{$\mathrm{AAT}\left({ }^{\circ} \mathrm{C}\right)$} & \multicolumn{2}{|c|}{ ST $\left({ }^{\circ} \mathrm{C}\right)$} & \multicolumn{2}{|c|}{ Rainfall (mm) } \\
\hline & A-W & W-S & A-W & W-S & A-W & W-S & A-W & W-S & A-W & W-S \\
\hline Tillering & 11 & 10 & 14 & 15 & 18 & 22 & 14 & 16 & 260 & 84 \\
\hline Booting & 10 & 10 & 14 & 15 & 19 & 22 & 14 & 16 & 341 & 176 \\
\hline Inflorescence & 11 & 11 & 15 & 16 & 20 & 22 & 15 & 17 & 547 & 411 \\
\hline Anthesis & 11 & 12 & 15 & 16 & 20 & 22 & 15 & 17 & 631 & 423 \\
\hline Watery ripe grain & 11 & 12 & 15 & 16 & 20 & 22 & 16 & 17 & 735 & 428 \\
\hline Soft dough grain & 11 & 12 & 15 & 17 & 21 & 23 & 16 & 17 & 745 & 558 \\
\hline Ripening & 11 & 12 & 15 & 17 & 21 & 23 & 16 & 18 & 771 & 558 \\
\hline Monthly average & 10.8 & 11.3 & 15.1 & 16.0 & 19.8 & 22.3 & 15.1 & 16.8 & - & - \\
\hline Total period & - & - & - & - & - & - & & & 4.030 & 2.638 \\
\hline
\end{tabular}

Quantitative data were first subjected to analysis of variance, followed by comparison of means using Tukey's test at 5\% error probability. Qualitative data were subjected to mode calculation (SUDRÉ et al., 2006). Based on the results of these procedures, those descriptors affected by genotype $\mathrm{x}$ environment $(\mathrm{G} \times \mathrm{E})$ interaction were selected and subjected to multivariate analysis, for assessing the distinctness between cultivars in both growing seasons. For quantitative data, average euclidean distance (d) was adopted as a measure of distinctness, assessing the relative trait contribution to genetic divergence (SINGH, 1981). After obtaining the quantitative distinctness matrix, clustering analysis was performed in order to define cultivar clusters with the same similarity pattern using hierarchical techniques. For qualitative data, multicategoric data were transformed into binary data to obtain the distinctness index matrix 3, wherein $0-0$ is computed as similarity and ranges from 0 to 1 , which corresponds to the average euclidean distance (CRUZ; CARNEIRO, 2006). Clustering method choice for dendrogram design was based on the cophenetic correlation coefficient, adopting a 50\% relative distance cutoff point. Statistical analysis was performed using Genes software (CRUZ, 2013).

Stability indices were proposed and defined in order to best compare descriptor and cultivar performance regarding environmental variation. For quantitative descriptors, the stability index $\left(\mathrm{SI}_{\mathrm{OTD}}\right)$ was assessed as follows: $\mathrm{SI}_{\mathrm{QTD}}: 1-\left|\frac{D A W-D W S}{D A W}\right|$, in which DAW= descriptor value assigned during the $\mathrm{A}-\mathrm{W}$ season and $\mathrm{DWS}=$ descriptor value assigned during the W-S season. The stability index of qualitative descriptors $\left(\mathrm{SI}_{\mathrm{OLD}}\right)$ was assessed using the following formula: $\mathrm{SI}_{\mathrm{QLD}}: 1-\left|\frac{V G}{G}\right|$, in which $\mathrm{VG}=$ number of genotypes in which the descriptor varied according to the growing season and $\mathrm{G}=$ total number of genotypes tested. Stability indices were on a scale from 0 to 1 , with 1 indicating high descriptor stability. Furthermore, for qualitative data, the average stability index of cultivars $\left(\mathrm{ASI}_{\mathrm{QLD}}\right)$ was calculated using the following formula: $\mathrm{ASI}_{\mathrm{QLD}}$ : $\mathrm{VD} / \mathrm{D}$, in which $\mathrm{VD}=$ number of variant descriptors and $\mathrm{D}=$ total number of descriptors affected by the growing season. 


\section{Results}

\section{Descriptor expression}

Out of the 42 descriptors, 12 were not affected by genotype (Table 2). Thus, oat cultivars displayed the same morphology for leaf sheath (absence), leaf margin (presence), upper node (presence), glume (absence), grain base (presence) and lemma external surface (absence) hairiness, spikelet position (decumbent), panicle branch direction (equilateral), lemma waxiness (absence), glume shape (pointy), hull (presence) and awn (presence). These traits as well as flag leaf length and lemma color were not affected by the environment, meaning that only 14 of the 42 analyzed descriptors were stable when the growing season was changed. The 28 other descriptors were affected by the environment, in that they showed expression instability upon environmental variation, and were affected by the $\mathrm{G} \times \mathrm{E}$ interaction, indicating that the phenotype of one or more cultivars changed in response to environmental changes. Expression stability following environmental changes was $7 \%$ for quantitative descriptors, because only 1 of the 15 traits were unaffected by environmental changes, and $44 \%$ for qualitative traits. Variation between qualitative traits observed for vegetative descriptors (66\%) was higher than that observed for reproductive descriptors (44\%).

Delayed sowing shortened the crop cycle, in all phases of phenological quantitative descriptors (Table 3). On average, the onset of different phases was an average of 6 (tillering), 10 (booting), 22 (complete booting and inflorescence), 24 (anthesis), 25 (ripening) and 27 (soft dough grain and watery ripe grain) days less from seedling emergence with late sowing. In the A-W growing season, the most and least stable phases were tillering $\left(\mathrm{SI}_{\mathrm{QTD}}=0.81\right)$ and complete booting $\left(\mathrm{SI}_{\mathrm{QTD}}=0.63\right)$, respectively. The highest $\mathrm{SI}_{\text {QTD }}$ were assessed in the G1 cultivar between the booting and watery ripe grain phases. From that phase, the G2 cultivar showed the lowest phenological variation due to the delay in the growing season. Conversely, G3 was the least stable cultivar, especially between tillering and complete booting phases.

Analysis of morphological quantitative descriptors affected by the $\mathrm{G} \times \mathrm{E}$ interaction (Table 4) showed that cultivar variability in the W-S growing season was less pronounced than in the A-W growing season. In the A-W growing season, cultivars displayed significant variation $(p>0.05)$ in all traits, albeit without differences in flag leaf width, panicle density and caryopsis length in the $\mathrm{W}-\mathrm{S}$ growing season. The most and least stable morphological descriptors were glume length $\left(\mathrm{SI}_{\mathrm{QTD}}=0.95\right)$ and flag leaf width $\left(\mathrm{SI}_{\mathrm{QTD}}=0.82\right)$, respectively (Table 4).

Analysis of qualitative descriptors whose expression changed in response to genotype and environment (Table 5) showed the following descending order of stability: upper node hairiness, flag leaf position, grain base hairiness, grain base hair length and rachilla length $\left(\mathrm{SI}_{\mathrm{QLD}}=0.8\right)>$ branch position $\left(\mathrm{SI}_{\mathrm{QLD}}=0.6\right)>$ growing habit, awn type, frequency of recurved flag leaf, flag leaf waxiness and tendency to awning $\left(\mathrm{SI}_{\mathrm{QLD}}=0.4\right)>$ leaf margin and caryopsis hairiness $\left(\mathrm{SI}_{\mathrm{QLD}}=0.2\right)>$ glume waxiness $\left(\mathrm{SI}_{\mathrm{QLD}}=0\right)$. Thus, the least stable qualitative descriptor was glume waxiness, in which all cultivars showed variation with the change to $\mathrm{W}-\mathrm{S}$ growing season. The most stable cultivars regarding these qualitative descriptors were $\mathrm{G} 2$ and $\mathrm{G} 5\left(\mathrm{ASI}_{\mathrm{QLD}}=0.71\right)$, whereas $\mathrm{G} 4$ was the least stable $\left(\mathrm{ASI}_{\mathrm{QLD}}=0.21\right)$. 
Table 2. Genotype (G), environment (E) and G x E interaction effect on the expression of 42 morphological and phenological descriptors evaluated in five oat cultivars grown in two growing seasons.

\begin{tabular}{|c|c|c|c|}
\hline Descriptors & Genotype & Environment & $\mathrm{G} \times \mathrm{E}$ \\
\hline \multicolumn{4}{|l|}{ A) Quantitative } \\
\hline 1. Flag leaf length & $\mathrm{x}^{*}$ & $-*$ & - \\
\hline 2. Glume length & $\mathrm{x}$ & $\mathrm{x}$ & $\mathrm{x}$ \\
\hline 3. Plant length & $\mathrm{x}$ & $\mathrm{x}$ & $\mathrm{x}$ \\
\hline 4. Panicle length & $\mathrm{x}$ & $\mathrm{x}$ & $\mathrm{x}$ \\
\hline 5. Caryopsis length & $\mathrm{x}$ & $\mathrm{x}$ & $\mathrm{x}$ \\
\hline 6. Panicle density & $\mathrm{x}$ & $\mathrm{x}$ & $\mathrm{x}$ \\
\hline 7. Flag leaf width & $\mathrm{x}$ & $\mathrm{x}$ & $\mathrm{x}$ \\
\hline 8. Tillering & $\mathrm{x}$ & $\mathrm{x}$ & $\mathrm{x}$ \\
\hline 9. Booting & $\mathrm{x}$ & $\mathrm{x}$ & $\mathrm{x}$ \\
\hline 10. Complete booting & $\mathrm{x}$ & $\mathrm{x}$ & $\mathrm{x}$ \\
\hline 11. Inflorescence & $\mathrm{x}$ & $\mathrm{x}$ & $\mathrm{x}$ \\
\hline 12. Anthesis & $\mathrm{x}$ & $\mathrm{x}$ & $\mathrm{x}$ \\
\hline 13. Watery ripe grain & $\mathrm{x}$ & $\mathrm{x}$ & $\mathrm{x}$ \\
\hline 14. Soft dough grain & $\mathrm{x}$ & $\mathrm{x}$ & $\mathrm{x}$ \\
\hline 15. Ripening & $\mathrm{x}$ & $\mathrm{x}$ & $\mathrm{x}$ \\
\hline \multicolumn{4}{|l|}{ B) Qualitative } \\
\hline \multicolumn{4}{|l|}{ (Vegetative) } \\
\hline 1. Growing habit & $\mathrm{x}$ & $\mathrm{x}$ & $\mathrm{x}$ \\
\hline 2. Leaf sheath hairiness & - & - & - \\
\hline 3. Leaf margin hairiness & - & - & - \\
\hline 4. Intensity of margin hairiness & $\mathrm{x}$ & $\mathrm{x}$ & $\mathrm{x}$ \\
\hline 5. Frequency of plants with recurved flag leaf & $\mathrm{x}$ & $\mathrm{x}$ & $\mathrm{x}$ \\
\hline 6. Flag leaf waxiness & $\mathrm{x}$ & $\mathrm{x}$ & $\mathrm{x}$ \\
\hline 7. Flag leaf position & $\mathrm{x}$ & $\mathrm{x}$ & $\mathrm{x}$ \\
\hline 8. Upper node hairiness & - & - & - \\
\hline 9. Intensity of upper node hairiness & $\mathrm{x}$ & $\mathrm{x}$ & $\mathrm{x}$ \\
\hline \multicolumn{4}{|l|}{ (Reproductive) } \\
\hline 10. Branch position & - & - & - \\
\hline 11. Branch direction & - & - & - \\
\hline 12. Spikelet position & $\mathrm{x}$ & $\mathrm{x}$ & $\mathrm{x}$ \\
\hline 13. Glume waxiness & $\mathrm{x}$ & $\mathrm{x}$ & $\mathrm{x}$ \\
\hline 14. Lemma waxiness & - & - & - \\
\hline 15. Glume shape & - & - & - \\
\hline 16. Glume hairiness & - & - & - \\
\hline 17. Presence of hull & - & - & - \\
\hline 18. Grain base hairiness & - & - & - \\
\hline 19. Caryopsis hairiness & $\mathrm{x}$ & $\mathrm{x}$ & $\mathrm{x}$ \\
\hline 20. Intensity of grain base hairiness & $\mathrm{x}$ & $\mathrm{x}$ & $\mathrm{x}$ \\
\hline 21. Grain base hair length & $\mathrm{x}$ & $\mathrm{x}$ & $\mathrm{x}$ \\
\hline 22. Rachilla length & $\mathrm{x}$ & $\mathrm{x}$ & $\mathrm{x}$ \\
\hline 23. Lemma color & $\mathrm{x}$ & - & - \\
\hline 24. Hairiness on the external surface of the lemma & - & - & - \\
\hline 25. Awn (presence/absence) & - & - & - \\
\hline 26. Tendency to awning & $\mathrm{x}$ & $\mathrm{x}$ & $\mathrm{x}$ \\
\hline 27. Awn type & $\mathrm{x}$ & $\mathrm{x}$ & $\mathrm{x}$ \\
\hline
\end{tabular}

$*_{\mathrm{x}}$ indicates effect; - indicates absence of effect. 
Table 3. Expression and stability index $\left(\mathrm{SI}_{\text {QTD }}\right)$ of phenological quantitative descriptors of oat grown in the $\mathrm{A}-\mathrm{W}$ and W-S growing seasons.

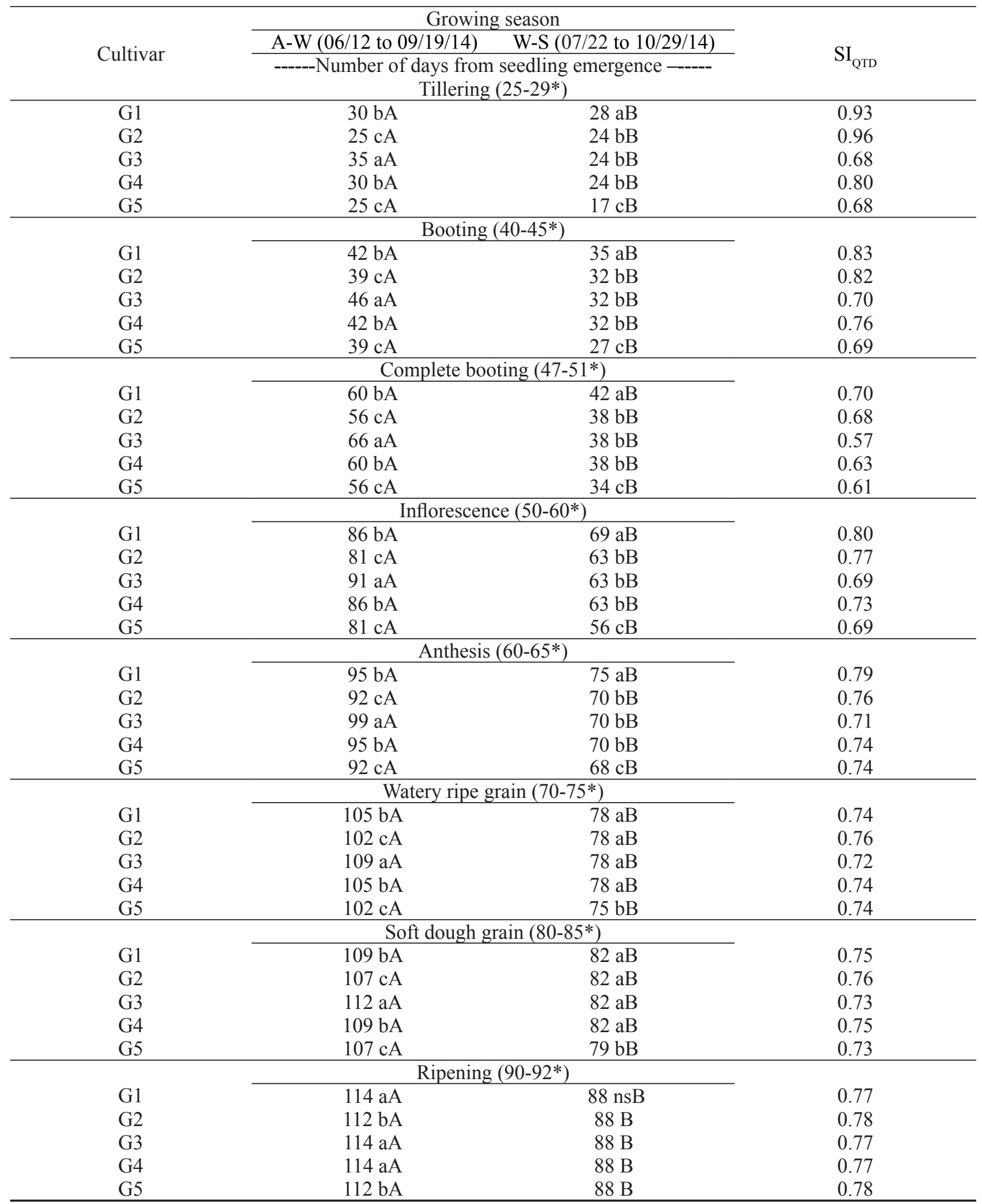

Means followed by the same letter, lowercase in columns and uppercase in rows, at each phase, are not significantly different according to Tukey's test ( $\mathrm{p}>0.05)$. *Scale by Zadoks et al. (1974). 
Table 4. Expression and stability index $\left(\mathrm{SI}_{\mathrm{QTD}}\right)$ of quantitative vegetative and reproductive descriptors of oat grown in the A-W and $\mathrm{W}-\mathrm{S}$ growing seasons.

\begin{tabular}{|c|c|c|c|}
\hline \multirow{2}{*}{ Cultivar } & \multicolumn{2}{|c|}{ Growing season } & \multirow{2}{*}{$\mathrm{SI}_{\mathrm{QTD}}$} \\
\hline & A-W (6/12 to $9 / 19 / 14)$ & $\mathrm{W}-\mathrm{S}(7 / 22$ to $10 / 29 / 14)$ & \\
\hline & \multicolumn{2}{|c|}{ Flag leaf width $(\mathrm{mm})$} & \\
\hline G1 & $16 \mathrm{bcA}$ & $12 \mathrm{nsB}$ & 0.75 \\
\hline $\mathrm{G} 2$ & $14 \mathrm{aA}$ & $13 \mathrm{~B}$ & 0.93 \\
\hline G3 & $16 \mathrm{abA}$ & $13 \mathrm{~B}$ & 0.81 \\
\hline G4 & $18 \mathrm{aA}$ & $12 \mathrm{~B}$ & 0.73 \\
\hline G5 & $14 \mathrm{abA}$ & $12 \mathrm{~B}$ & 0.88 \\
\hline \multicolumn{4}{|c|}{ Panicle density $(\mathrm{cm} /$ internode $)$} \\
\hline G1 & $2.3 \mathrm{bB}$ & $3.1 \mathrm{nsA}$ & 0.66 \\
\hline $\mathrm{G} 2$ & $3.5 \mathrm{aA}$ & $3.1 \mathrm{~B}$ & 0.89 \\
\hline G3 & $2.8 \mathrm{bB}$ & $3.1 \mathrm{~A}$ & 0.90 \\
\hline G4 & $2.6 \mathrm{bB}$ & $3.1 \mathrm{~A}$ & 0.81 \\
\hline G5 & $3.2 \mathrm{aA}$ & $3.3 \mathrm{~A}$ & 0.97 \\
\hline \multicolumn{4}{|c|}{ Glume length II (mm) } \\
\hline G1 & $20 \mathrm{cB}$ & $21 \mathrm{aB}$ & 0.93 \\
\hline $\mathrm{G} 2$ & $23 \mathrm{bA}$ & $22 \mathrm{aA}$ & 0.96 \\
\hline G3 & $22 \mathrm{bA}$ & $22 \mathrm{aA}$ & 1.00 \\
\hline G4 & $26 \mathrm{aA}$ & $23 \mathrm{aB}$ & 0.89 \\
\hline G5 & $20 \mathrm{cA}$ & $19 \mathrm{bA}$ & 0.96 \\
\hline \multicolumn{4}{|c|}{ Plant length $(\mathrm{cm})$} \\
\hline G1 & $111 \mathrm{abA}$ & $103 \mathrm{bB}$ & 0.93 \\
\hline $\mathrm{G} 2$ & $110 \mathrm{abA}$ & $105 \mathrm{abA}$ & 0.95 \\
\hline G3 & $112 \mathrm{abA}$ & $112 \mathrm{aA}$ & 1.00 \\
\hline G4 & $117 \mathrm{aA}$ & $99 \mathrm{bcB}$ & 0.85 \\
\hline G5 & $105 \mathrm{bA}$ & $91 \mathrm{cB}$ & 0.87 \\
\hline \multicolumn{4}{|c|}{$\begin{array}{l}\text { Panicle length }(\mathrm{cm}) \\
\end{array}$} \\
\hline G1 & $17 \mathrm{cB}$ & $19 \mathrm{bcA}$ & 0.90 \\
\hline $\mathrm{G} 2$ & $24 \mathrm{aA}$ & $20 \mathrm{abB}$ & 0.84 \\
\hline G3 & $17 \mathrm{cB}$ & $21 \mathrm{aA}$ & 0.79 \\
\hline G4 & $16 \mathrm{cB}$ & $18 \mathrm{cA}$ & 0.94 \\
\hline G5 & $20 \mathrm{bA}$ & $18 \mathrm{cB}$ & 0.90 \\
\hline \multicolumn{4}{|c|}{ Caryopsis length $(\mathrm{mm})$} \\
\hline G1 & $7.8 \mathrm{bA}$ & $8.0 \mathrm{nsA}$ & 0.98 \\
\hline $\mathrm{G} 2$ & $9.3 \mathrm{aA}$ & $8.4 \mathrm{~B}$ & 0.91 \\
\hline G3 & $8.0 \mathrm{bA}$ & $8.4 \mathrm{~A}$ & 0.95 \\
\hline G4 & $9.4 \mathrm{aA}$ & $8.3 \mathrm{~B}$ & 0.89 \\
\hline G5 & $7.1 \mathrm{cB}$ & $7.8 \mathrm{~A}$ & 0.91 \\
\hline
\end{tabular}

Means followed by the same letter, lowercase in columns and uppercase in rows, are not significantly different according to Tukey's test ( $p>0.05)$; ns: non-significant $(\mathrm{p}>0.05)$. 


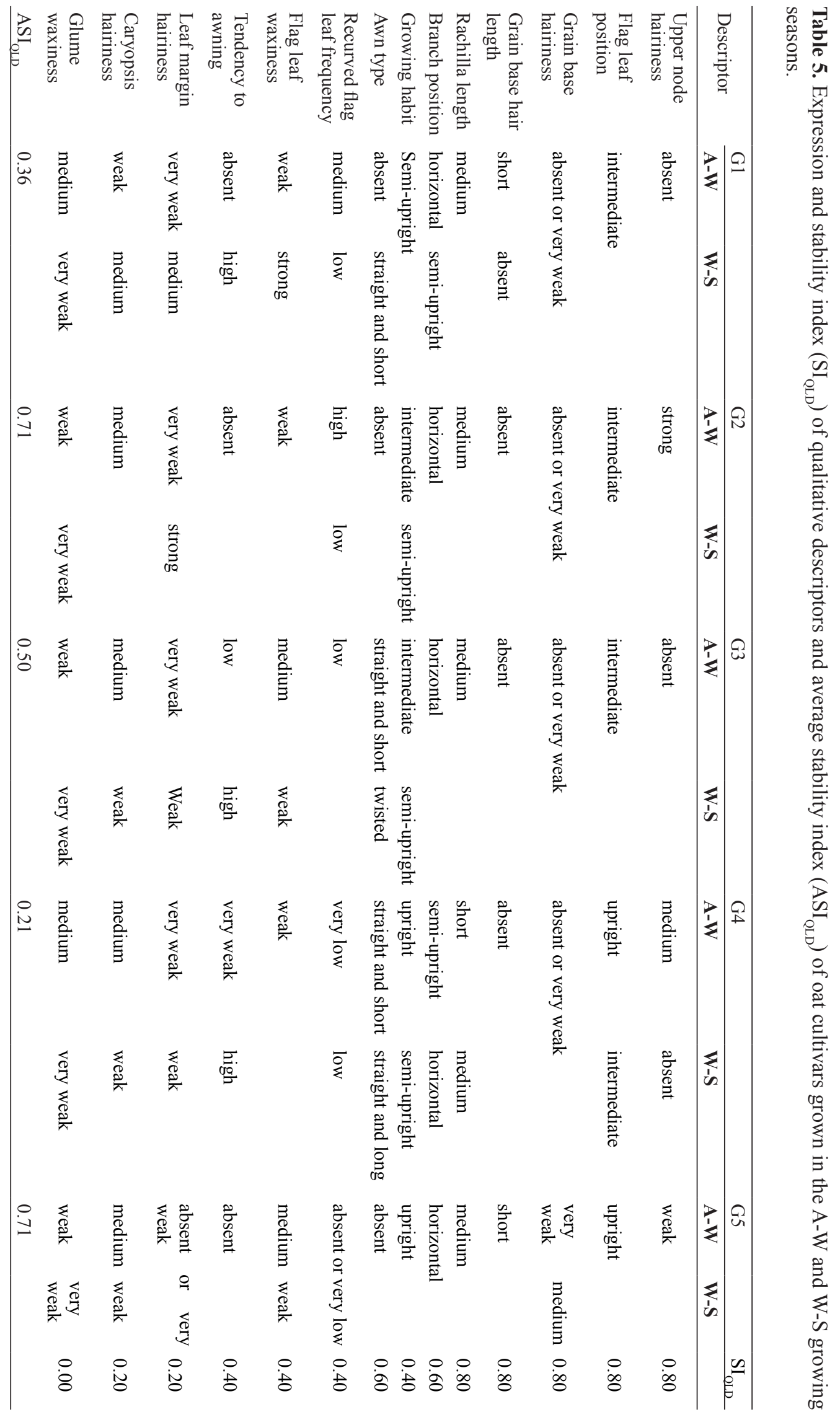




\section{Phenotypic divergence}

Phenotypic divergence of the analyzed cultivars was quantified using average euclidean distance (d) and the similarity coefficient. As illustrated in the dendrograms designed using the Ward clustering method (Figures 1 and 2), phenotypic distinctness varied with the growing season. However, three clusters were formed in both seasons and for both quantitative and qualitative descriptors, indicating the phenotypic variability between the analyzed cultivars. Variation in the relative contribution to genetic divergence (RCDG) of quantitative traits (Table 6) occurred in both growing seasons, which helped characterize the clusters formed.

In the A-W growing season, during which inflorescence, tillering and complete booting phases, and plant length showed the highest RCDG (Table 6), the main trait of the cluster formed by G1 and G4 cultivars was plant length $(114 \mathrm{~cm})$, which was higher than the other two clusters (Figure 1A). The cluster formed by G3 cultivar had phenological phases that were markedly later, and the cluster formed by G2 and G5 cultivars showed the highest phenological precocity and shortest plant length $(107 \mathrm{~cm}$; Figure 1A). The greatest distinctness in the A-W growing season was observed between $\mathrm{G} 2$ and G3 cultivars $(\mathrm{d}=0.81)$ and the lowest was observed between $\mathrm{G} 1$ and $\mathrm{G} 4(\mathrm{~d}=0.37)$. Conversely, in the $\mathrm{W}-\mathrm{S}$ growing season, the traits with the highest RCDG were panicle, glume, caryopsis and plant length (Table 5). The cluster formed by cultivars G2 and $\mathrm{G} 3$ in the dendrogram (Figure 1B) showed the longest plant, panicle, glume and caryopsis length. The cluster formed by G1 cultivar displayed the most delayed performance between tillering and watery ripe grain phases. Conversely, the cluster formed by G4 and G5 cultivars was characterized by the highest phenological precocity and shortest plant and panicle length. The greatest distinctness between cultivar pairs in the W-S growing season was observed between $\mathrm{G} 1$ and $\mathrm{G} 5(\mathrm{~d}=0.76)$ and the lowest was observed between $\mathrm{G} 2$ and G3 (d=0.37).

In the A-W growing season, illustration of phenotypic distinctness between cultivars for qualitative data shows that the cluster formed by G2 and G3 cultivars grouped plants with intermediate flag leaf position, medium rachilla length and absence of grain base hairs (Figure 2A). The cluster consisting of G1 and G5 cultivars was characterized by short grain base hairs, and the cluster containing the G4 cultivar was characterized by upright flag leaf position and short rachilla length (Figure 2A). Conversely, in the W-S growing season, the relationships between cultivars were different (Figure 2B). One cluster grouped the G3 and G4 cultivars together, based on the absence of upper node hairiness. G1 and G2 cultivars were located together in another group, based on intermediate flag leaf position and absence of grain base hairs. The G5 cultivar formed a separate cluster, based on plants with upright flag leaf position, weak upper node hairiness and short grain base hairs (Figure 2B). 
Figure 1. Dendrogram of distinctness between five oat cultivars grown in the A-W (A) and W-S (B) growing seasons, designed using the Ward clustering methods, based on the euclidean average distance matrix with quantitative data. Relative genetic distances are on the $\mathrm{x}$-axis and genotype description on the $\mathrm{y}$-axis.

(A)

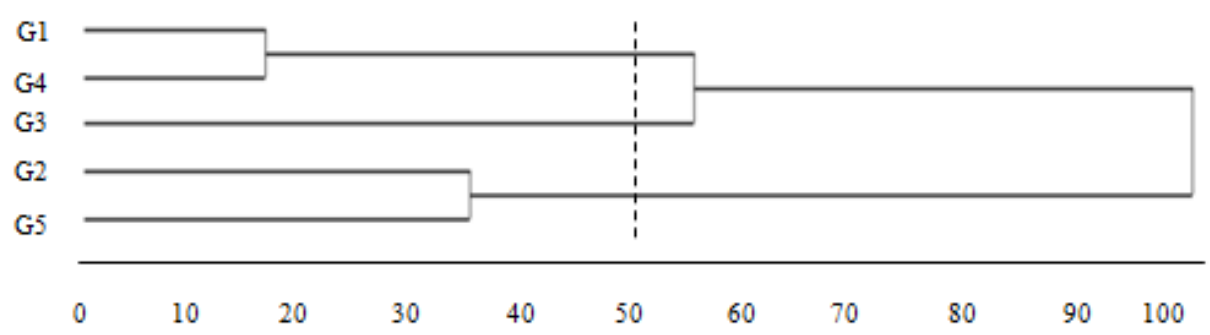

(B)

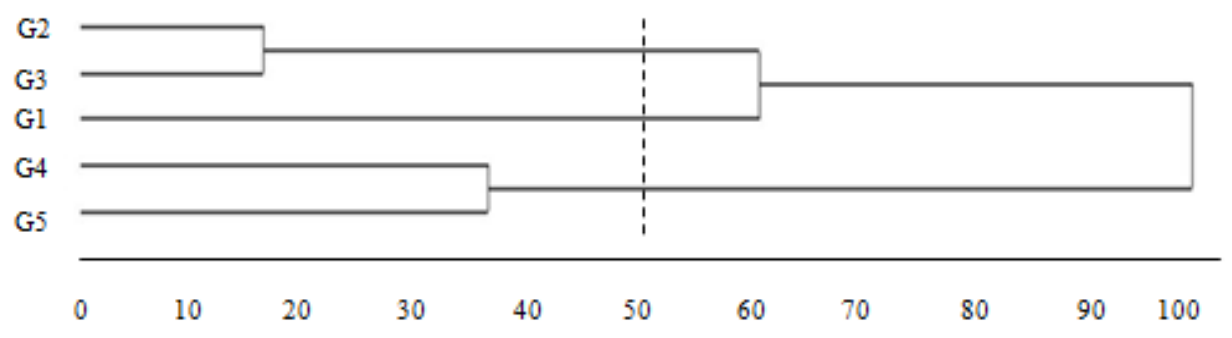

Figure 2. Dendrogram of distinctness between five oat cultivars grown in the A-W (A) and W-S (B) growing seasons, designed using the Ward clustering method, based on the average euclidean distance matrix with qualitative data. Relative genetic distances are on the $\mathrm{x}$-axis and genotype description on the $\mathrm{y}$-axis.

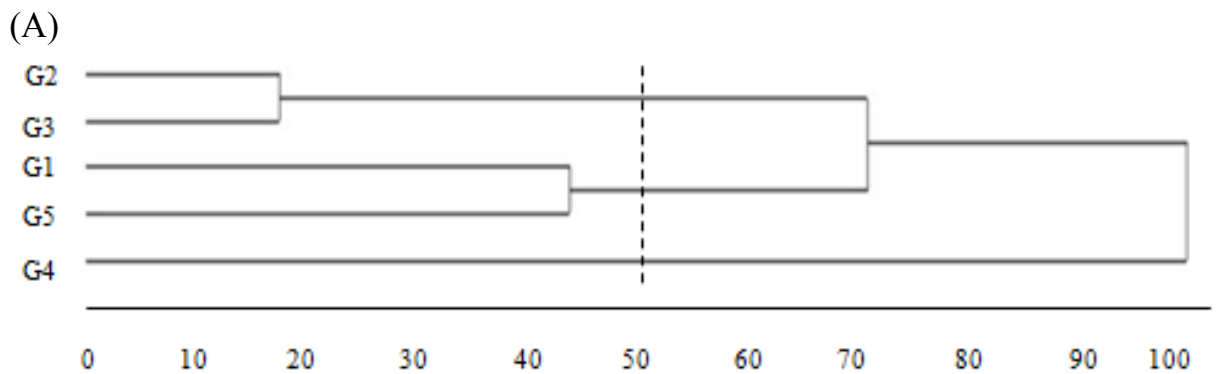

(B)

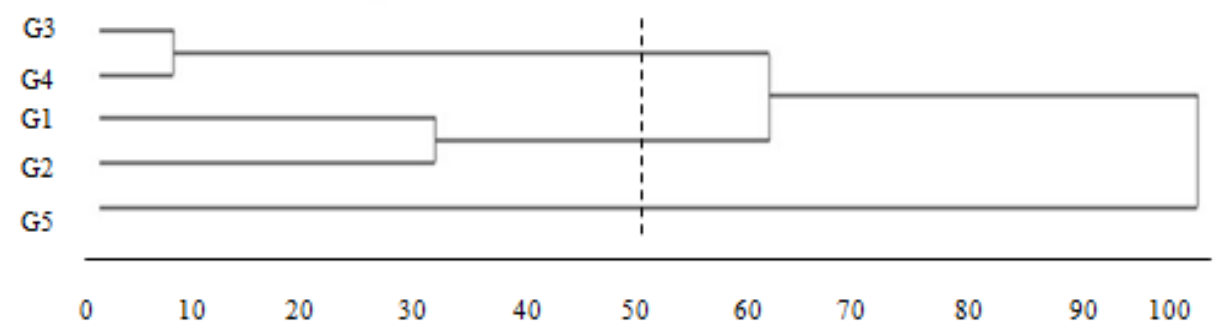


Table 6. Relative contribution of quantitative traits to genetic divergence (SINGH, 1981) of oat cultivars grown in the $\mathrm{A}-\mathrm{W}$ and $\mathrm{W}-\mathrm{S}$ growing seasons.

\begin{tabular}{lrc}
\hline \multirow{2}{*}{ Trait } & \multicolumn{2}{c}{ Season } \\
\cline { 2 - 3 } & A-W & W-S \\
\cline { 2 - 3 } & 5.02 & 12.97 \\
\hline Glume length & 13.45 & 11.29 \\
Plant length & 8.15 & 13.36 \\
Panicle length & 0.79 & 12.91 \\
Caryopsis length & 0.18 & 7.10 \\
Panicle density & 1.32 & 0.40 \\
Flag leaf width & 13.87 & 13.66 \\
Tillering & 6.58 & 9.62 \\
Booting & 13.32 & 1.28 \\
Complete booting & 19.84 & 3.49 \\
Inflorescence & 6.58 & 4.68 \\
Anthesis & 6.58 & 5.15 \\
Watery ripe grain & 3.33 & 4.73 \\
Soft dough grain & 0.95 & 0.00 \\
Ripening & & \\
\hline
\end{tabular}

\section{Discussion}

Expression evaluation of Avena L. morphological and phenological descriptors of showed that a shift in the growing season affected almost all quantitative and, to a lesser extent, qualitative traits. Indeed, the $\mathrm{G} \times \mathrm{E}$ interaction affects the relationships between traits by changing the relative expression of one trait in two or more genotypes, evaluated in two or more settings (BOWMAN, 1972). In the present study, variation in the magnitude or state of descriptors affected the relationship between cultivars, by reducing or increasing distinctness between them. Evaluation using descriptors are efficient in understanding the science (DIEDERICHSEN, 2009) and the DUS test effectively assessed differences between genotypes and analyzed the reliability of descriptors in the present study.

The environmental variation to which the cultivars were subjected to was created by sowing at two different dates, which was adequate to create different temperature and rainfall conditions. In the $\mathrm{W}-\mathrm{S}$ growing season, higher average air and soil temperatures and lower rainfall were recorded than in the A-W growing season (Table 1). Prevailing weather conditions in each growing season changed the expression of descriptors (Tables 3, 4 and 6) and, therefore, the morphology and phenology of cultivars in each growing season, which affected their level of distinctness (Figures 1 and 2). The timing of sowing is one of the most important crop management practices, precisely because it leads to variable temperature and rainfall conditions (SUBEDI et al., 2007).

The present study demonstrated a range of descriptor responses to genotype $\mathrm{x}$ environment effects. Ineffective descriptors, of which there were 12, did not differ between genotypes. Effective and reliable descriptors, which were flag leaf length and lemma color, differed between genotypes but were unaffected by environmental changes (Table 2). Lemma color is the most obvious oat trait, according to Coffman (1964). In the present study, lemma color displayed total stability with variation in the growing season, thereby corroborating other studies on oat (BOCZKOWSKA; TARCZYK, 2013). Flag leaf length, which is not currently listed as an Avena L. descriptor (BRASIL, 2002), displayed stability to environmental variation. However, as flag leaf 
length depends on levels of nitrogen fertilization (SONEGO et al., 1999), use of this descriptor places emphasis on complying with fertilization management guidelines in DUS tests. In maize (Zea mays L.), leaf blade length is considered one of the minimum descriptors for hybrid protection (BRASIL, 1997).

Crop production in the $\mathrm{A}-\mathrm{W}$ growing season allowed genotypes to meet the differentiation, homogeneity and stability criteria recommended by the MAPA (BRASIL, 2011). Conversely, crop production in the W-S growing season caused genotypes to shorten their phenological phases and it was not possible to differentiate between them following the watery ripe grain phase. Oat has been reported to develop best when subject to relatively low average temperatures before flowering, ranging from 15 to $20^{\circ} \mathrm{C}$, (LOCATELLI et al., 2008; CASTRO et al., 2012; NAVEED et al., 2015), as occurred in the A-W growing season (Table 1). However, the period between sowing and ripening depends on the cultivar, temperature, and photoperiod (BROUWER; FLOOD, 1995). Therefore, cultivars sown in autumn tend to have longer crop cycles than those grown in the spring (SONEGO, 2000).

Abiotic stresses accelerate the development of phenological phases in plants (CASTRO et al., 2012), which was observed for plant grown in the W-S growing season (Table 1). In addition to potential abiotic stress conditions, soil temperature noticeably increased from 15 to $17{ }^{\circ} \mathrm{C}$ with the delay in growing season (Table 1), which may have also affected the phenology of cultivars as soil temperatures have been reported to affect plant growth and development (MOTA, 1989).

In the A-W growing season, the seedling emergence to ripening cycle was 113 days on average for each genotype. However, in the W-S growing season, the complete cycle was 25 days shorter. The seedling emergence to ripening cycle is a key trait in differentiating between cultivars and important for the variety protection process. This trait is inherent to the genotype (MENEZES et al., 2011), although variation in cycle duration may occur owing to the timing of sowing and weather conditions (FONSECA et al., 2008). Oat plants typically prefer long days and, thus, short nights, which promotes early flowering (LOCATELLI et al., 2008). These conditions were present in the W-S growing season. In Spain, Oteros et al. (2015) reported phenological phase shortening when oat was grown in the spring, and reduced time-to-flowering by one day/year resulting from the temperature increase over 26 years of observation.

The delay in growing season changed expression of 28 morphological descriptors of oat genotypes, including 14 quantitative and 14 qualitative descriptors, meaning that $67 \%$ of all traits tested experienced $\mathrm{G} \times \mathrm{E}$ interaction. Among descriptors affected by the environment, most genotypes $(60 \%)$ had shorter panicle length in the $\mathrm{A}-\mathrm{W}$ growing season than in the W-S growing season. Shorter panicle length is selected for in oat breeding because the decrease in inflorescence determines the increase in grain number, thereby increasing oat yield (CARVALHO; FEDERIZZI, 1989). However, as assessed in the present study, use of panicle length will decisively differentiate between genotypes because it is weakly affected by environmental changes (BONOW et al., 2007). Conversely, in all genotypes apart from G3, panicle density, calculated by measuring the rachilla length divided by the number of internodes, increased with the delay in growing season. The change observed in this descriptor may have resulted partly from decreased rainfall in the $\mathrm{W}-\mathrm{S}$ growing season (Table 1), as water deficiency affects both cell division and elongation, which influences internode growth (MACHADO et al., 2009).

Overall, final plant height for all genotypes decreased by $10 \mathrm{~cm}$ in the W-S growing season (Table 3), which, according to MAPA classification, changed their classification from long $(111 \mathrm{~cm})$ to medium $(101 \mathrm{~cm})$ with the delay in sowing. In 
agreement, Marchioro et al. (2001) reported an average reduction of $14 \mathrm{~cm}$ in oat cultivar height with the delay in sowing season.

In terms of phenotypic distinctness, the relationship between genotypes was changed when the delay in growing season for both quantitative and qualitative descriptors (Figures 1 and 2). Therefore, as was observed in the present study, the phenotypic profile of a cultivar observed outside of the recommended growing season may be undifferentiating for several traits. The results of this study illustrate the importance of understanding $G \times E$ interaction effects, and emphasize that the reliability of morphological and phenological descriptors to reflect genetic similarity between cultivars may change depending on the growing season.

\section{Conclusions}

The delay in oat growing season, from A-W to $\mathrm{W}-\mathrm{S}$, reduces the crop cycle and changes the expression of most morphological and phenological descriptors, changing the phenotypic divergence between cultivars. The most stable oat descriptors are lemma color and flag leaf length.

\section{References}

BEZERRA NETO, F. V.; LEAL, N. R.; GONÇALVES, L. S. A.; FILHO, L. de M. R.; AMARAL JÚNIOR, A. T. do. Descritores quantitativos na estimativa da divergência genética entre genótipos de mamoneira utilizando análises multivariadas. Revista Ciência Agronômica, Fortaleza, v. 41, n. 2, p. 294-299, 2010.

BIOVERSITY INTERNATIONAL. Guidelines for the development of crop descriptor lists. Rome: Bioversity International, 2007. (Bioversity Technical Bulletin Series, 13).

BOCZKOWSKA, M.; TARCZYK, E. Genetic diversity among Polish landraces of common oat (Avena sativa L.). Genetic Resources Crop Evolution, Dordrecht, v. 60, n. 7, p. 2157-2169, 2013.

BONOW, S.; VILELA, E.; PINHO, R. V.; SOARES, A. A.; SIECOLA JÚNIOR, S. Caracterização morfológica de genótipos de arroz visando a certificação da pureza varietal. Ciência e Agrotecnologia, Lavras, v. 31, n. 3, p. 619-627, 2007.

BOWMAN, J. C. Genotype $\times$ environment interactions. Annales de Génétique et de Sélection Animale, Paris, v. 4, n. 1, p. 117-123, 1972.

BRASIL. Instruções para execução dos ensaios de distinguibilidade, homogeneidade e estabilidade de genótipos de milho (Zea mays L.). Ministério da Agricultura, Pecuária e Abastecimento: Brasília, 1997. $12 \mathrm{p}$.

Instruções para execução dos ensaios de distinguibilidade, homogeneidade e estabilidade de genótipos de aveia (Avena spp.). Ministério da Agricultura, Pecuária e Abastecimento: Brasília, 2002. $12 \mathrm{p}$.

- Proteção de Cultivares no Brasil. Ministério da Agricultura, Pecuária e Abastecimento. Secretaria de Desenvolvimento Agropecuário e Cooperativismo: Brasília, 2011. 202 p.

BROUWER, J. B.; FLOOD, R. G. Aspects of oat physiology. In: WELCH, R. W. (Ed.). The oat crop: production and utilization. Chapman \& Hall: London, 1995. p. 177-222.

CARVALHO, F. I. F.; FEDERIZZI, L. C. Evolução da cultura da aveia no sul do Brasil. Trigo e Soja, Porto Alegre, v. 102, n. 18, p. 16-19, 1989.

CASTRO, G. S. A.; COSTA, C. H. M.; FERRARI NETO, J. Ecofisiologia da aveia branca. Scientia Agraria Paranaensis, Cascavel, v. 11, n. 3, p. 1-15, 2012.

COFFMAN, F. A. Inheritance of morphologic characters in Avena. Washington: Agricultural Research Service, United States Department of Agriculture, 1964. (Technical Bulletin, 1308).

COMISSÃO BRASILEIRA DE PESQUISA DE AVEIA - CBPA. Indicações técnicas para cultura da aveia. Passo Fundo; Universidade de Passo Fundo, 2014. 136 p.

CRUZ, C. D. Genes: a software package for analysis in experimental statistics and quantitative genetics. Acta Scientiarum Agronomy, Maringá, v. 35, n. 3, p. 271-276, 2013.

CRUZ, C. D.; CARNEIRO, P. C. S. Modelos biométricos aplicados ao melhoramento genético. 2. ed. Viçosa: Editora UFV, 2006. 585 p.

DIEDERICHSEN, A. Assessments of genetic diversity within a world collection of cultivated hexaploid oat (Avena sativa L.) based on qualitative morphological characters. Genetic Resources and Crop Evolution, Dordrecht, v. 55, n. 3, p. 419-440, 2008. 
. Duplication assessments in nordic Avena sativa accessions at the Canadian national genebank. Genetic Resources and Crop Evolution, Dordrecht, v. 56, n. 4, p. 587-597, 2009.

FLARESSO, J. A.; GROSS, C. D.; ALMEIDA, E. X. Época e densidade de semeadura de aveia preta (Avena strigosa Schreb.) e azevém (Lolium multiflorum Lam.) no Alto Vale do Itajaí, Santa Catarina. Revista Brasileira de Zootecnia, Viçosa, v. 30, n. 6, p. 1969-1974, 2001.

FONSECA, J. R.; CUTRIM, V. A.; RANGEL, P. H. N.; MORAIS, O. P.; CASTRO, A. P.; GUSMÃO, A. R. E.; FARIA, J. M. Descritores morfoagronômicos e fenológicos de linhagens de arroz (Oriza sativa L.) de várzeas e de terras altas. Embrapa Arroz e Feijão, 2008. (Documentos, 219).

GUIMARÃES, W. N. R.; MARTINS, L. S. S.; SILVA, E. F.; FERRAZ, G. M. G.; OLIVEIRA, F. J. Caracterização morfológica e molecular de acessos de feijão-fava (Phaseolus lunatus L.). Revista Brasileira de Engenharia Agrícola e Ambiental, Campina Grande, v. 11, n. 1, p. 3745, 2007.

INTERNATIONAL BOARD OF PLANT GENETIC RESOURCES - IBPGR. Oats descriptors. Rome: IBPGR, 1985.

JEHANGIR, I. A.; KHAN, H. U.; KHAN, M. H.; URRASOOL, F.; BHAT, R. A.; MUBARAK, T.; BHAT, M. A.; RASOOL, S. Effect of sowing dates, fertility levels and cutting managements on growth, yield and quality of oats (Avena sativa L.). African Journal of Agricultural Research, Nairobi, v. 8, n. 7, p. 648-51, 2013.

LOCATELLI, A. B.; FEDERIZZI, L. C.; MILACH, S. C. K.; MCELROY E. R. Flowering time in oat: Genotype characterization for photoperiod and vernalization response. Field Crops Research, Wageningen, v. 106, n. 3, p. 242-247, 2008.

MACHADO, R. S.; RIBEIRO, R. V.; MARCHIORI, P. E. R.; MACHADO, D. F. S. P.; MACHADO, E. C.; LANDELL, M. G. A. Respostas biométricas e fisiológicas ao déficit hídrico em cana-de-açúcar, em diferentes fases fenológicas. Pesquisa Agropecuária Brasileira, Brasília, v. 44, n. 12, p. 1575-1582, 2009.

MALUF, J. R. T. Nova classificação climática do Estado do Rio Grande do Sul. Revista Brasileira de Agrometeorologia, Santa Maria, v. 8, n. 1, p. 141-150, 2000.

MARCHIORO, V. S.; CARVALHO, F. I. F.; OLIVEIRA, A. C.; KUREK, A. J.; LORENCETTI, C.; SILVA, J. A. G.; CARGNIN, A. Estratégias para a modificação do potencial de rendimento de grãos em genótipos de aveia: época de semeadura e aplicação de fungicida. Revista Brasileira de Agrociência, Pelotas, v. 7, n. 1, p. 33-36, 2001.

MENEZES, B. R. S.; MOREIRA, L. B.; LOPES, H. M.; PEREIRA, M. B. Caracterização morfoagronômica em arroz vermelho e arroz de sequeiro. Pesquisa Agropecuária Tropical, Goiânia, v. 41, n. 4, p. 490-499, 2011.

MOTA, F. S. Meteorologia agrícola. São Paulo: Nobel, 1989. $201 \mathrm{p}$.

NAVEED, K.; KHAN, M. A.; BALOCH, M. S.; ARIF, M.; NAQVI, A. S.; KHAN, J.; ALI, S. Early planting date can compensate the reduction in wheat yield due to fodder cutting in dual purpose wheat. Pakistan Journal Agricultural Sciences, Lahore, v. 52, n. 2, p. 467-475, 2015.

OTEROS, J.; GARCÍA-MOZO, H.; BOTEY, R.; MESTRE, A.; GALÁN, C. Variations in cereal crop phenology in Spain over the last twenty-six years (19862012). Climatic Change, Dordrecht, v. 130, n. 4, p. 545$558,2015$.

SINGH, D. The relative importance of characters affecting genetic divergence. The Indian Journal of Genetic and Plant Breeding, New Delhi, v. 41, n. 2, p. 237-245, 1981.

SONEGO, M. Effect of temperature and daylength on the phenological development of oats (Avena sativa L.). 2000. Tesis (Doctoral Thesis/Philosophy) - Lincoln University, New Zealand.

SONEGO, M.; JAMIESON, P. D.; MOOT, D. J., MARTIN, R. J. Development and growth of oat leaves at different temperatures and nitrogen levels. Journal Agronomy, New Zealand, v. 29, n. 2, p. 75-81, 1999.

SUBEDI, K. D.; MA, B. L.; XUE, A. G. Planting date and nitrogen effects on grain yield and protein content of spring wheat. Crop Science, Madison, v. 47, n. 1, p. 36-47, 2007.

SUDRÉ, C. P.; CRUZ, C. D.; RODRIGUES, R.; RIVA, E. M.; KARASAWA, M.; AMARAL JUNIOR, A. T. Variáveis multicategóricas na determinação da divergência genética entre acessos de pimenta e pimentão. Horticultura Brasileira, Brasília, v. 24, n. 1, p. 88-93, 2006.

VALÉRIO, I. P.; CARVALHO, F. I. F.; OLIVEIRA, A. C.; LORENCETTI, C.; SOUZA, V. Q.; SILVA, J. A. G; HARWIG, I.; SCHMIDT, D. A. M.; BERTAN, I.; RIBEIRO, G. Estabilidade da produção e da capacidade de combinação de diferentes populações de aveia. Semina, Londrina, v. 30, n. 2, p. 331-346, 2009. 
VALLE, J. I. J. Descriptores varietales de Avena (Avena sp.) cultivadas en México. 2009. Dissertação (Mestrado em Ciências) - Instituición de Ensenanza e Investigación em Ciências Agrícolas, México.
ZADOKS, J. C.; CHANG, T. T.; KONZAC, C. F. A decimal code for the growth stages of cereals. Weed Research, Council, v. 14, n. 1, p 415-421, 1974. 